\title{
Antinociceptive effect of the ethanolic extract of Neoglaziovia variegata (Bromeliaceae) in mice
}

\author{
Sarah Raquel Gomes de Lima-Saraiva ${ }^{1}$, Henrique César Costa Saraiva ${ }^{2}$, Juliane Cabral Silva ${ }^{2}$, \\ Julianeli Tolentino de Lima ${ }^{2}$, José Alves de Siqueira-Filho ${ }^{2}$, \\ Patrícia Kauanna Fonseca Damasceno ${ }^{3}$, Carla Rodrigues Cardoso Branco ${ }^{3}$, \\ Alexsandro Branco ${ }^{3}$, Elba Lúcia Cavalcanti Amorim ${ }^{1}$ and \\ Jackson Roberto Guedes da Silva Almeida ${ }^{2 *}$ \\ ${ }^{1}$ Federal University of Pernambuco, Recife, Pernambuco, Brazil. \\ ${ }^{2}$ Federal University of São Francisco Valley, Petrolina, Pernambuco, Brazil. \\ ${ }^{3}$ State University of Feira de Santana, Feira de Santana, Bahia, Brazil.
}

Accepted 23 February, 2012

\begin{abstract}
This study was carried out to evaluate the antinociceptive effects of ethanolic extract from Neoglaziovia variegata (Nv-EtOH) in mice using models of nociception. The evaluation of antinociceptive activity was carried out by the acetic acid-induced writhing, formalin and hot plate tests. HPLC was used to determine the fingerprint chromatogram of the Nv-EtOH. In the acetic acid-induced writhing test, the NvEtOH $(100,200$ and $400 \mathrm{mg} / \mathrm{kg}$, i.p.) reduced the number of writhing by $89.50,71.34$ and $87.42 \%$, respectively. Additionally, the extract decreased by $46.67,44.23$ and $41.81 \%$, respectively, the paw licking time in the first phase of the formalin test, as well as $70.14,69.43$ and $90.28 \%$, respectively, in the second phase of this test. In the hot plate test, Nv-EtOH increased the reaction time when compared to control group. The effects of $\mathrm{Nv}-\mathrm{EtOH}$ and morphine in the formalin and hot plate tests were antagonized by naloxone. The presence of phenolic compounds in the extract was confirmed using HPLC. Results based from formalin and hot plate tests indicated that the extract has compounds that interact with the opioid system. The effect of $\mathrm{Nv}$-EtOH on hot plate response provides a confirmation of its central effect. Pharmacological and chemical studies are continuing in order to characterize the mechanism responsible for this effect.
\end{abstract}

Key words: Antinociceptive activity, phenolic compounds, Neoglaziovia variegata, Bromeliaceae.

\section{INTRODUCTION}

Sensory systems have the role of informing the brain about the state of the external environment and the internal milieu of the organism. Pain is a perception, and as such, it is one of the outputs of a system in more highly evolved animals- the nociceptive system -which itself is a component of the overall set of controls responsible for homeostasis (Le Bars et al., 2001). Pain is a sensorial modality which in many cases represents the only symptom for the diagnosis of several diseases. It

*Corresponding author. E-mail: jackson.guedes@univasf.edu. br. Tel/Fax: + 55-87-21016862. often has a protective function. Throughout history man has used many different forms of therapy for the relief of pain, among them, medicinal herbs are highlighted due to their wide popular use (Almeida et al., 2001).

The effective treatment of the pain continues to be one of the major challenges in healthcare. While analgesics that target the central opioid system are highly effective, these drugs are associated to respiratory-depressant effects as well as the development of tolerance to prolonged applications (Buzzi et al., 2010). Non-steroidal anti-inflammatory drugs (NSAIDs), steroidal drugs and immunosuppressant drugs, have been usually used in the relief of pain and inflammatory diseases by the people of the world for a long time. However, these drugs 
were often associated with severe adverse side effects, such as gastrointestinal bleeding and peptic ulcers (Corley et al., 2003). Recently, many natural medicines derived from plants, marine organisms, etc, were considered as the effective and safer for the treatment of various diseases including inflammation and pain (Su et al., 2011).

Medicinal plants are alternative options to conventional therapies to many diseases, and Brazil with its enormous biodiversity can contribute to the search of new natural products and bioactive molecules (Vieira-de-Abreu et al., 2005). The Brazilian flora remains poorly studied with regard to its chemical and pharmacological potential. Thus, the purpose of this study was to evaluate the pharmacological potential of Neoglaziovia variegata, a species belonging to the family Bromeliaceae.

The Bromeliaceae, one of the largest botanical families of the New World, is distributed extensively in tropical America (Chedier and Kaplan, 1996). This family comprises 58 genera and 3172 species (Luther, 2008). Considering the large number of species of the Bromeliaceae family few have been studied chemically so far. Despite this, there is a considerable amount of identified compounds, which mostly belong to the class of triterpenoid and flavonoids. Other classes of compounds such as sterols, diterpenes, cinnamic acids, glycerol replaced, lignans, nitrogen compounds, among others, were also identified in this family, although greatly reduced in number.

From the pharmacological standpoint, there are also few studies in the literature (Manetti et al., 2009). Extracts of Nidularium procerum showed anti-allergic properties (Vieira-de-Abreu et al., 2005) as well as analgesic and anti-inflammatory properties (Amendoeira et al., 2005). Antiulcer activity of ethanolic extract of Encholirium spectabile was also demonstrated (Carvalho et al., 2010).

The family Bromeliaceae fascinates by the exuberance, diversity and beauty of its species (Rocha et al., 2010). Neoglaziovia variegata is a species native to the lower stratum of the Brazilian Caatinga. It has striped leaves, flowers protected by bracts with bright coloration and fruits as juicy berries. This species is known in the Northeast Region of Brazil as "caroá" and constitutes one of the most used raw materials for use in craftsmanship in the region, generating jobs and income for many families. Its leaves are used in fiber extraction which is used for manufacturing string, hats, purses, rugs, hammocks, fishing nets and fabrics. The caroá plant, however, has been collected directly in the Caatinga in a extrativism manner, without any systematization of cultivation, having practically disappeared in some regions (Silveira et al., 2009).

There is no previous report on the analysis of the antinociceptive activity of Neoglaziovia variegata. In our continuing search of the medicinal plants from Brazilian Caatinga for combine biodiversity conservation with drug discovery, the aim of this study was to evaluate the antinociceptive activity of ethanolic extract of $N$. variegata in experimental models.

\section{MATERIALS AND METHODS}

\section{Plant material}

The leaves of $N$. variegata (Arruda) Mez were collected in the city of Petrolina, State of Pernambuco, Brazil, in January of 2011. The samples were identified by André Paviotti Fontana, a botanist from Centro de Recuperação de Áreas Degradadas da Caatinga (CRAD). A voucher specimen (6441) was deposited at the Herbarium Vale do São Francisco (HVASF) of the Federal University of São Francisco Valley.

\section{Extraction}

The leaves dried and pulverized (581 g) were macerated with ethanol $95 \%$ at room temperature for $72 \mathrm{~h}$. The solution was filtered and concentrated under reduced pressure in a rotatory evaporator oven at $50^{\circ} \mathrm{C}$, producing $30 \mathrm{~g}$ of crude ethanol extract (Nv-EtOH).

\section{Analysis of Nv-EtOH by high performance liquid chromatography (HPLC)}

The analysis of phenolic compounds profile were performed in liquid chromatograph Hitachi model Lachrom Elite, colunm LiCospher $100 \mathrm{RP} 18(5 \mathrm{~mm})$ with dimensions $(150 \mathrm{~mm} \times 04 \mathrm{~mm})$ Merck equipped with Diode Array Detector (DAD). The mobile phase used was a solution of $\mathrm{H}_{2} \mathrm{O} / \mathrm{H}_{3} \mathrm{PO}_{4} 0.1 \%(A)$ and $\mathrm{MeOH}(\mathrm{B})$ provided initial $75 \%$ of $A$ and $25 \%$ of $B$ for $25 \mathrm{~min}$. The column temperature was kept constant at $30^{\circ} \mathrm{C}$ with a flow of $1.0 \mathrm{ml} / \mathrm{min}$. For the extract was used an injection volume of $20 \mu \mathrm{l}$. Spectral data were recorded in $322 \mathrm{~nm}$ during the whole run.

\section{Animals}

Male and female adult albino Swiss mice (25-35 g) were used throughout this study. The animals were randomly housed in appropriate cages at $22 \pm 2{ }^{\circ} \mathrm{C}$ on a $12 \mathrm{~h}$ light/ dark cycle (lights on at 6:00 a.m.) with free access to food and water. When necessary, animals were deprived of food $12 \mathrm{~h}$ prior to the experiments. They were used in groups of five or six animals each. All nociception tests were carried out by the same visual observer. Experimental protocols and procedures were approved by the Federal University of São Francisco Valley Animal Care and Use Committee by number 21051023.

\section{Acute toxicity}

In the inquiry of the acute toxicity, groups of five male and five female Swiss mice $(n=10)$ were administered intraperitoneally 2.0 and $5.0 \mathrm{~g} / \mathrm{kg}$ orally of the crude ethanol extract of $N$. variegata (Nv$\mathrm{EtOH})$. Control group received vehicle. Mortality in each group within $72 \mathrm{~h}$ was recorded and the animals were observed during a period of 14 days for the presence of toxicity signals (Araújo et al., 2008).

\section{Acetic acid-induced writhing in mice}

This test was performed as described by Koster et al. (1959) with 


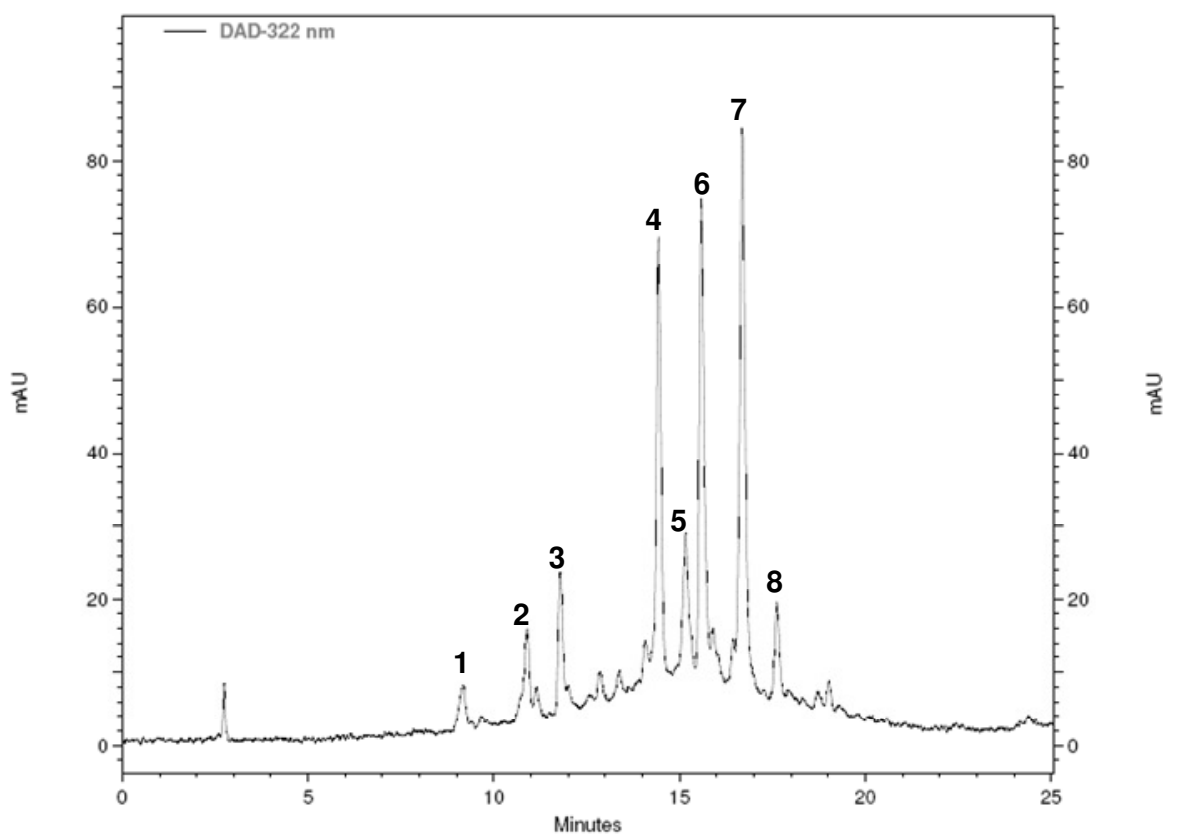

Figure 1. High performance liquid chromatography with diode array detector (HPLCDAD) profiles of Neoglaziovia variegata ethanolic extract recorded at $322 \mathrm{~nm}$.

modifications. Male mice $(n=6)$ were intraperitoneally pre-treated 30 min before the nociceptive agent, acetic acid $0.9 \%(\mathrm{v} / \mathrm{v}, 10$ $\mathrm{ml} / \mathrm{kg}$ ). Vehicle (saline), Nv-EtOH (100, 200 and $400 \mathrm{mg} / \mathrm{kg}$, body weight), acetylsalicylic acid (ASA, $200 \mathrm{mg} / \mathrm{kg}$ ) and morphine (10 $\mathrm{mg} / \mathrm{kg}$ ) were administered before acetic acid injection. Following the injection of acetic acid, the intensity of nociceptive behavior was quantified by counting the total number of writhes (a response consisting of contraction of the abdominal wall, pelvic rotation followed by hind limb extension) occurring between 5 and $15 \mathrm{~min}$ after injection (Queiroz et al., 2010).

\section{Formalin test}

The method used was similar to that described previously (Shibata et al., 1989; Vianna et al., 1998; Oliveira et al., 2009). Twenty microlitres of $2.5 \%$ formalin was injected subcutaneously into the right hind paw of male mice. The time (in seconds) spent in licking and biting responses of the injected paw was taken as an indicator of pain response. Responses were measured for $5 \mathrm{~min}$ after formalin injection (first phase, neurogenic phase) and 15-30 min after formalin injection (second phase, inflammatory phase). NvEtOH $(100,200$ and $400 \mathrm{mg} / \mathrm{kg})$, ASA $(200 \mathrm{mg} / \mathrm{kg})$ and morphine $(10 \mathrm{mg} / \mathrm{kg}$ ) were administered intraperitoneally $60 \mathrm{~min}$ before formalin injection. Control animals received the same volume of saline. Mice were observed in the chambers with a mirror mounted on three sides to allow view of the paws.

\section{Hot plate test}

Male mice were pre-selected on the hot plate at $55 \pm 0.5^{\circ} \mathrm{C}$. Licks on the rear paws were the parameters of observation. Animals showing a reaction time (latency for licking the hind feet or jumping) greater than $10 \mathrm{~s}$ were discarded. The animals were then treated with vehicle (saline, $0.1 \mathrm{ml} / 10 \mathrm{~g}$ ), morphine $(10 \mathrm{mg} / \mathrm{kg}$ ) and $\mathrm{Nv}$ $\mathrm{EtOH}(100,200$ and $400 \mathrm{mg} / \mathrm{kg}$ ) via i.p. Latency time (in seconds) for each mice was determined on the hot plate during the maximum period of $20 \mathrm{~s}$, at intervals of $30,60,90$ and $120 \mathrm{~min}$ after the administration of the extract (Almeida et al., 2011).

\section{Statistical analysis}

The data obtained from animal experiments were analyzed using the GraphPad Prism program version 4.0 and expressed as mean \pm S.E.M. Statistically significant differences between groups were calculated by the application of analysis of variance (ANOVA) followed by Dunnett's test. Values were considered significantly different at $\mathrm{P}<0.05$.

\section{RESULTS}

\section{Analysis of Nv-EtOH by high performance liquid chromatography (HPLC)}

Phenolic profiles at $322 \mathrm{~nm}$ for the $\mathrm{Nv}$-EtOH evaluated are presented in Figure 1. The chromatogram shows the presence of eight peaks with different retention times: 9.60 (1), 10.89 (2), 11.80 (3), 14.44 (4), 15.16 (5), 15.58 (6), 16.69 (7) and $17.62(8)$. Based on their UV-Vis spectral data and their retention time, the compounds have UV band characteristic for cinnamic acid, coumarin and flavonoid derivatives. These compounds are under investigation.

\section{Acute toxicity}

In the acute toxicity evaluation of $\mathrm{Nv}-\mathrm{EtOH}$, behavioral 
and physiological alterations were not observed neither animal's death in the doses of $2.0 \mathrm{~g} / \mathrm{kg}$ intra-peritoneally and $5.0 \mathrm{~g} / \mathrm{kg}$ orally, respectively, indicating low toxicity of the extract.

\section{Acetic acid-induced writhing in mice}

Figure 2 shows that the i.p. administration of $\mathrm{Nv}$ - $\mathrm{EtOH}$ $(100,200$ e $400 \mathrm{mg} / \mathrm{kg})$ decreased significantly $(P<0.01)$ the number of writhing movements induced by the i.p. administration of the acetic acid compared with the control group. The inhibitions of writhes in percentage were $89.50,71.34$ and $87.42 \%$, respectively.

\section{Formalin test}

The formalin test revealed an antinociceptive effect of the extract (Figure 3a and 3b). Nv-EtOH caused a significant inhibition of both neurogenic and inflammatory phases in the licking induced by formalin. The result was most significative in the inflammatory phase. Nv-EtOH (100, 200 and $400 \mathrm{mg} / \mathrm{kg}$, i.p.) decreased by $46.67,44.23$ and $41.81 \%$, respectively, the paw licking time in the first phase, as well as $70.14,69.43$ and $90.28 \%$, respectively, in the second phase of the formalin test.

The pretreatment with naloxone $(1.5 \mathrm{mg} / \mathrm{kg}$, i.p.) reversed the antinociceptive activity of the extract at dose of $400 \mathrm{mg} / \mathrm{kg}$ in the first phase of this test. The effect of morphine $(10 \mathrm{mg} / \mathrm{kg})$ was also reversed by naloxone.

\section{Hot plate test}

In the hot plate test (Figure 4), the animals treated with $\mathrm{Nv}$-EtOH at dose of $200 \mathrm{mg} / \mathrm{kg}$ showed an increase in latency time at 60 and $120 \mathrm{~min}$. This effect was most significant at a dose of $400 \mathrm{mg} / \mathrm{kg}$, which showed a marked increase latency time in 60, 90 and $120 \mathrm{~min}$. The effects of $\mathrm{Nv}$-EtOH and morphine were inhibited by naloxone, which completely reversed the antinociceptive effect in the hot plate model.

\section{DISCUSSION}

The present study showed the antinociceptive effect of the $N$. variegata extract in different nociceptive responses generated by a chemical or thermal noxious stimulus. Three different animal models were used in this study to investigate the potential antinociceptive of the ethanolic extract. The methods for investigating antinociception were selected based on their capacity to investigate both centrally and peripherally mediated effects. The abdominal constriction induced by acetic acid and the hot plate methods investigate peripheral and central activity, respectively, while the formalin test investigates both (Queiroz et al., 2010).

The extract intraperitoneally administered significantly reduced $(P<0.01)$, in all doses, the acetic acid-induced writhings in mice. Intraperitoneal injection of acetic acid produced $23.83 \pm 2.60$ writhes in the control group for 10 min after injection. The groups previously treated with 100,200 and $400 \mathrm{mg} / \mathrm{kg}$ of $\mathrm{Nv}$-EtOH exhibited a significant reduction in the number of writhings of 89.50 , 71.34 and $87.42 \%$, respectively. The results revealed that $\mathrm{Nv}$-EtOH has a potent antinociceptive activity in this method. The acetic acid-induced writhing test was commonly considered as classical peripheral analgesic animal model and widely used for screening analgesic drugs (Negus et al., 2006). Although this test is a nonspecific model of nociception, it is widely used for analgesic screening and involves local peritoneal receptors, which are thought to be partially responsible for abdominal constriction response. Some researchers have associated this method with prostanoids in general, i.e., increased levels of $P \mathrm{PE}_{2}$ and $\mathrm{PGF}_{2 \alpha}$, as well as lypoxigenase products in peritoneal fluids (Verma et al., 2005). However, it is important to note that other type of analgesics, such as the opioids, are also effective in this test without inhibiting COX or LOX.

In order to distinguish between the central and peripheral antinociceptive action, the formalin test was performed. The formalin test is a valid and reliable model of nociception and is sensitive for various classes of analgesic drugs. Formalin test produced a distinct biphasic response and different analgesics may act differently in the early and late phases of this test. Intraplantar injection of formalin makes two phases of painful sensitivity evident. The first or acute phase (0-5 min) classified as neurogenic pain is caused by direct activation of type $\mathrm{C}$ nociceptive afferent fibers, releasing neuropeptides such as substance $\mathrm{P}$, among others. The second or tonic phase (15-30 $\mathrm{min})$ is characterized as inflammatory pain, related to release of chemical mediators such as histamine, serotonin, bradykinin, prostaglandins and excitatory aminoacids, which can be inhibited by painkillers and anti-inflammatory drugs (Tjolsen et al., 1992; Pereira et al., 2010). This test is a very useful method for not only assessing the antinociceptive drugs but also helping in the elucidation of the action mechanism (Shibata et al., 1989). Centrally acting drugs such as narcotics inhibit both phases. Peripheral acting drugs such as NSAIDs and corticoids inhibit mainly the second phase. The extract was able to act in both phases of the formalin response although the effect was more pronounced in the second phase. The effect of extract on the first and second phases of formalin test suggests that its activity may be resulted from its central action when compared with morphine activity in this respect. The pretreatment with naloxone reversed the antinociceptive activity of the extract in the first phase of this test. The results suggest a possible 


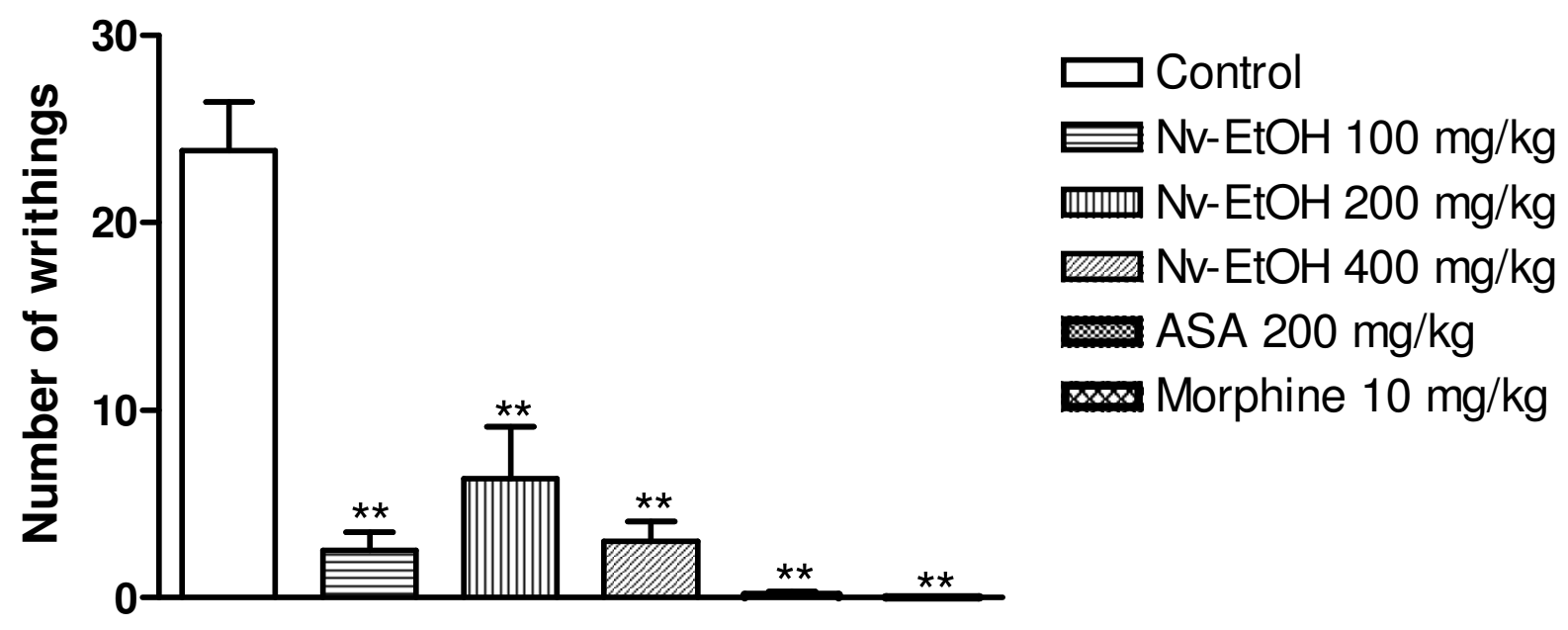

Figure 2. Effect of ethanolic extract of the Neoglaziovia variegata (Nv-EtOH), acetylsalicylic acid (ASA) and morphine on acetic acid induced writhing test. Values are mean \pm S.E.M. ${ }^{*} \mathrm{P}<0.01$, significantly different from control; ANOVA followed Dunnett's test ( $n=6$, per group).

(a)

First phase

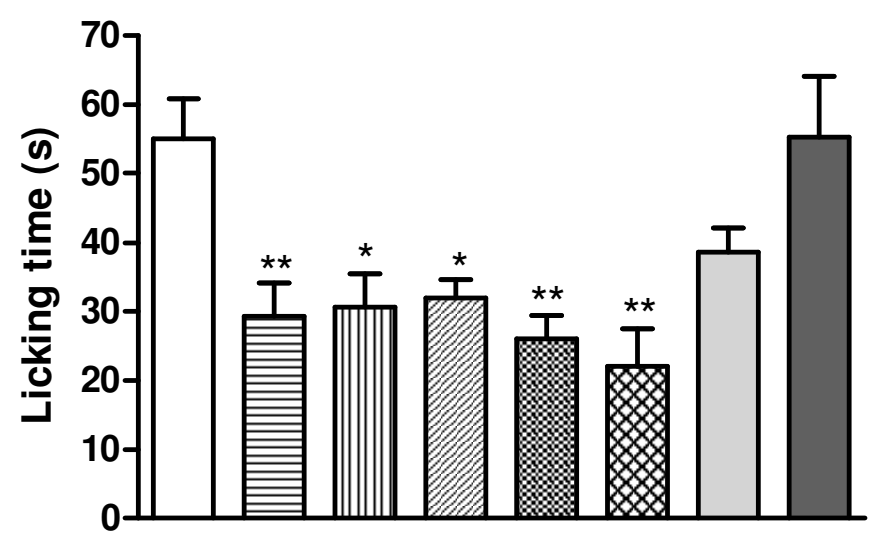

$\square$ Control

$\Longrightarrow \mathrm{Nv}-\mathrm{EtOH} 100 \mathrm{mg} / \mathrm{kg}$

血西 Nv-EtOH $200 \mathrm{mg} / \mathrm{kg}$

Nv-EtOH 400 mg/kg

ASA $200 \mathrm{mg} / \mathrm{kg}$

Morphine $10 \mathrm{mg} / \mathrm{kg}$

Morph + NLX

$\square \mathrm{Nv}-\mathrm{EtOH}+\mathrm{NLX}$

(b)

Second phase

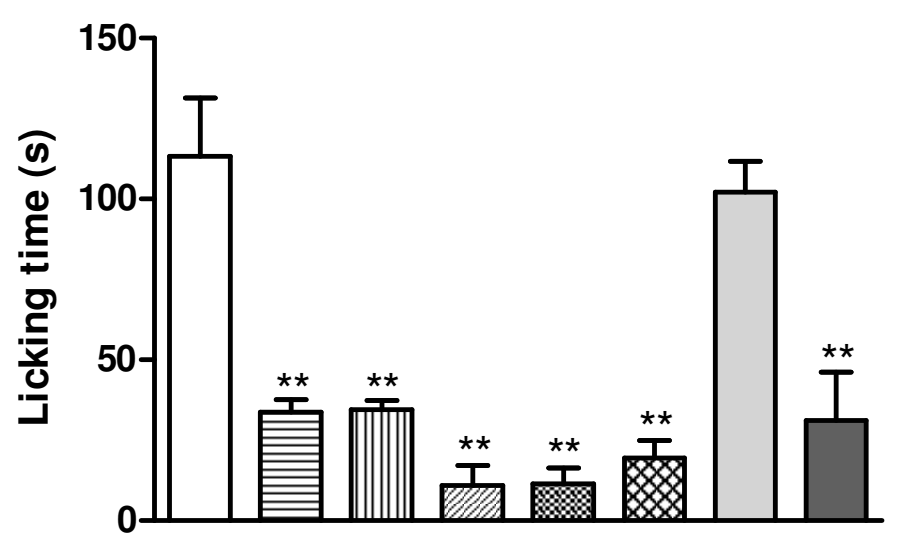

$\square$ Control

$\Longrightarrow \mathrm{Nv}-\mathrm{EtOH} 100 \mathrm{mg} / \mathrm{kg}$ 血 $\mathrm{Nv}$-EtOH 200 mg/kg Nv-EtOH 400 mg/kg ASA $200 \mathrm{mg} / \mathrm{kg}$ Morphine $10 \mathrm{mg} / \mathrm{kg}$ Morph + NLX Nv-EtOH + NLX

Figure 3. Effect of ethanolic extract of Neoglaziovia variegata (Nv-EtOH), acetylsalicylic acid (ASA), morphine, morphine + naloxone (Morph + NLX; $10 \mathrm{mg}+1.5 \mathrm{mg} / \mathrm{kg})$ and Nv-EtOH + NLX (400 mg + $1.5 \mathrm{mg} / \mathrm{kg}$ ) on formalin test. Values are mean \pm S.E.M.; ${ }^{\star} \mathrm{P}<0.05$, ${ }^{*} \mathrm{P}<0.01$, significantly different from control; ANOVA followed Dunnett's test ( $n=6$, per group). 


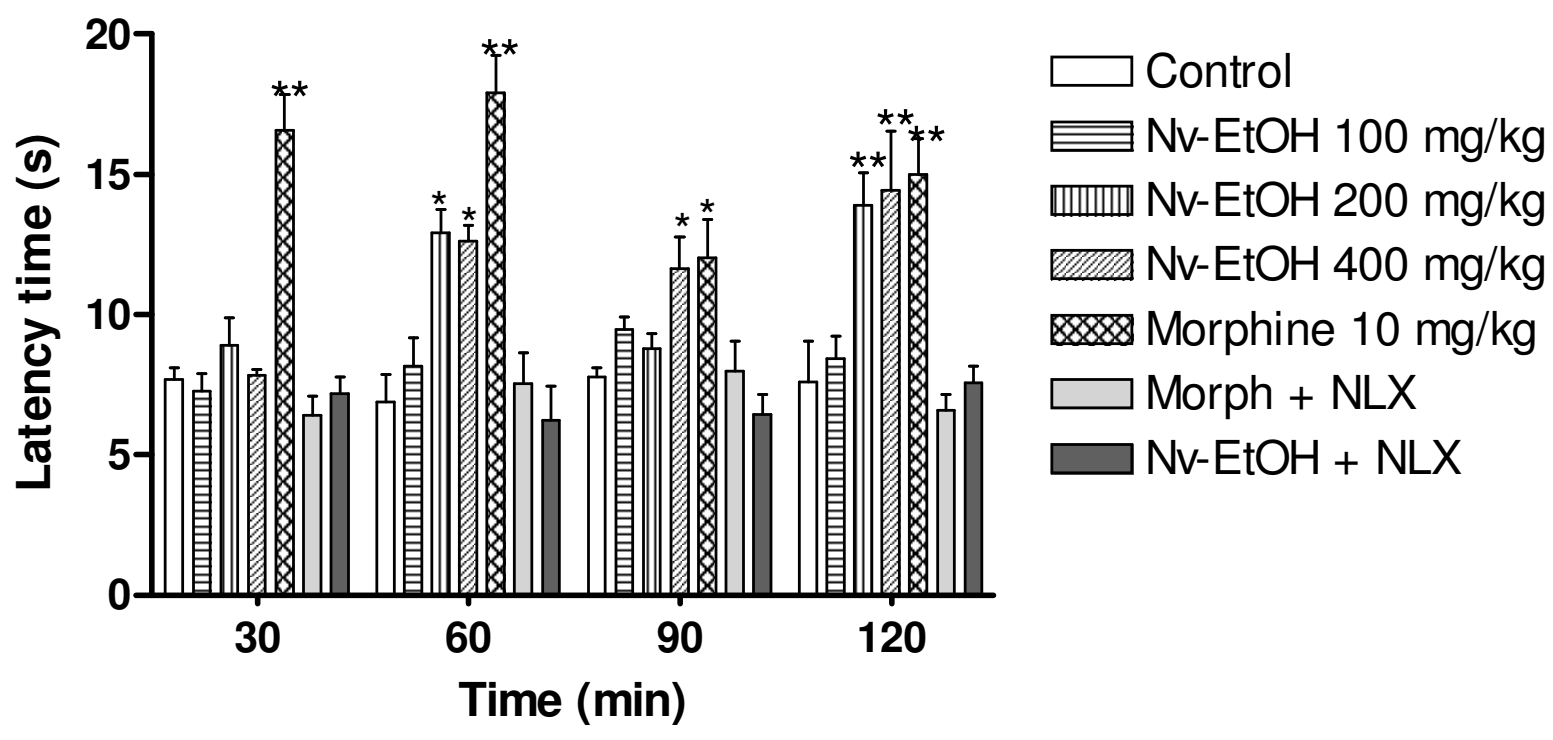

Figure 4. Effect of ethanolic extract of Neoglaziovia variegata $(\mathrm{Nv}-\mathrm{EtOH})$, morphine, morphine + naloxone (Morph + $\mathrm{NLX} ; 10 \mathrm{mg}+1.5 \mathrm{mg} / \mathrm{kg})$ and Nv-EtOH + NLX $(400 \mathrm{mg}+1.5 \mathrm{mg} / \mathrm{kg})$ on hot plate test. Values are mean \pm S.E.M.; ${ }^{*} \mathrm{P}<0.05,{ }^{* *} \mathrm{P}<0.01$, significantly different from control; ANOVA followed Dunnett's test ( $n=6$, per group).

involvement of opioid receptors in the antinociceptive effect of the extract.

The effect of $\mathrm{Nv}-\mathrm{EtOH}$ on hot plate response provides a confirmation of its central effect. Trying to elucidate the mechanism by which Nv-EtOH induces antinociception, animals were pre-treated with naloxone. The antinociceptive effect could be antagonized by naloxone, indicating an interaction with brain opioid mechanisms. The hot plate test is a central model that has selectivity for opioid-derived analgesics, such as morphine. Although the central and peripheral analgesics respond by inhibiting the number of contractions provoked by chemical pain stimuli, only the central analgesics increase the time of response in the hot plate test (Garcia et al., 2004). These results induce to think that the antinociceptive action of the extract, probably is more related to a central mechanism than with a peripheral mechanism.

Taken together, the results of our study suggest that the ethanolic extract from the leaves of $N$. variegata possess an antinociceptive effect, which probably is related with a central mechanism. The exact mechanism and the bioactive principles responsible for this effect remain to be explained. Pharmacological and chemical studies are continuing in order to characterize the mechanism responsible for this effect.

\section{ACKNOWLEDGEMENTS}

This work was supported by grants from Brazilian agencies CNPq (Process 476770/2010-6) and FACEPE (Process APQ-0542-4.03/10). The authors wish to express their thanks to Centro de Referência para
Recuperação de Áreas Degradadas (CRAD/UNIVASF) for collection and botanical identification of the plant material.

\section{REFERENCES}

Almeida JRGS, Lima JT, Oliveira HR, Oliveira MR, Meira PRM, Lúcio ASSC, Barbosa-Filho JM, Quintans-Júnior LJ (2011). Antinociceptive activity of discretamine isolated from Duguetia moricandiana. Nat. Prod. Res. 25:1908-1915.

Almeida RN, Navarro DS, Barbosa-Filho JM (2001). Plants with central analgesic activity. Phytomedicine 8:310-322.

Amendoeira FC, Frutuoso VS, Chedier LM, Pearman AT, Figueiredo MR, Kaplan MA, Prescott SM, Bozza PT, Castro-Faria-Neto HC (2005). Antinociceptive effect of Nidularium procerum: A Bromeliaceae from the Brazilian coastal rain Forest. Phytomedicine 12:78-87.

Araújo AAS, Bonjardim LR, Mota EM, Albuquerque-Júnior RLC, Estevam CS, Cordeiro L, Seixas SRS, Batista JS, Quintans-Júnior LJ (2008). Antinociceptive activity and toxicological study of aqueous extract of Egletes viscosa Less (Asteraceae). Braz. J. Pharm. Sci. 44:707-715.

Buzzi F, de C, Fracasso M, Filho VC, Escarcena R, del Olmo E, San Feliciano A (2010). New antinociceptive agents related to dihydrosphingosine. Pharmacol. Rep. 62:849-857.

Carvalho KIM, Fernandes HB, Machado FDF, Oliveira IS, Oliveira FA, Nunes PHM, Lima JT, Almeida JRGS, Oliveira RCM (2010). Antiulcer activity of ethanolic extract of Encholirium spectabile Mart. ex Schult \& Schult f. (Bromeliaceae) in rodents. Biol. Res. 43:459-465.

Chedier LM, Kaplan MAC (1996). Chemical ecology of three species of Bromeliaceae. Bromelia 3:25-31.

Corley DA, Kerlikowske K, Verma R, Buffler P (2003). Protective association of aspirin/NSAIDs and esophageal cancer: A systematic review and meta-analysis. Gastroenterology 124:47-56.

Garcia MD, Fernández MA, Alvarez A, Saenz MT (2004). Antinociceptive and anti-inflammatory effect of the aqueous extract from leaves of Pimenta racemosa var. ozua (Mirtaceae). J. Ethnopharmacol. 91:69-73.

Koster R, Anderson M, De Beer EJ (1959). Acetic acid for analgesic screening. Fed Proc. 18:412-416. 
Le Bars D, Gozariu M, Cadden SW (2001). Animal models of nociception. Pharmacol. Rev. 53:597-652.

Luther HE (2008). An alphabetical list of bromeliad binomials. Sarasota, Bromeliad Soc. Int., pp. 123.

Manetti LM, Delaporte RH, Laverde-Junior A (2009). Metabólitos secundários da família Bromeliaceae. Quim. Nova 7:1885-1897.

Negus SS, Vanderah TW, Brandt MR, Bilsky EJ, Becerra L, Borsook D (2006). Preclinical assessment of candidate analgesic drugs: Recent advances and future challenges. J. Pharmacol. Exp. Ther. 319:507514.

Oliveira RRB, Góis RMO, Siqueira RS, Almeida JRGS, Lima JT, Nunes XP, Oliveira VR, Siqueira JS, Quintans-Júnior LJ (2009). Antinociceptive effect of the ethanolic extract of Amburana cearensis (Allemão) A.C. Sm., Fabaceae, in mice. Braz. J. Pharmacog. 19:672676.

Pereira SS, Lopes LS, Marques RB, Figueiredo KA, Costa DA, Chaves $\mathrm{MH}$, Almeida FR (2010). Antinociceptive effect of Zanthoxylum rhoifolium Lam. (Rutaceae) in models of acute pain in rodents. J. Ethnopharmacol. 129:227-231.

Queiroz AC, Lira DP, Dias TL, Souza ET, Matta CB, Aquino AB, Silva LH, Silva DJ, Mella EA, Agra MF, Barbosa-Filho JM, Araújo-Júnior JX, Santos BV, Alexandre-Moreira MS (2010). The antinociceptive and anti-inflammatory activities of Piptadenia stipulacea Benth. (Fabaceae). J. Ethnopharmacol. 128:377-383.

Rocha FD, Yano M, Cunha MR, Gabriel FT, Cordeiro RSB, Menezes FS, Kaplan MAC (2010). Brazilian Bromeliaceae species: Isolation of arylpropanoid acid derivatives and antiradical potential. Braz. J. Pharmacog. 20:240-245.

Shibata M, Ohkubo T, Takahashi H, Inoki R (1989). Modified formalin test: characteristic biphasic pain response. Pain 38:347-352.

Silveira DG, Souza FVD, Pelacani CR, Souza AS, Ledo CAS, Santana JRF (2009). Micropropagation and in vitro conservation of $N$. variegata (Arr. Cam.) Mez, a fiber producing Bromeliad from Brazil. Braz. Arch. Biol. Technol. 52:923-932.

Su S, Wang T, Duan JA, Zhou W, Hua YQ, Tang YP, Yu L, Qian DW (2011). Anti-inflammatory and analgesic activity of different extracts of Commiphora myrrha. J. Ethnopharmacol. 134:251-258.
Tjolsen A, Berge OG, Hunskaar S, Rosland JH, Hole K (1992). The formalin test: an evaluation of the method. Pain 51:5-17.

Verma PR, Joharapurkar AA, Chatpalliwar VA, Asnani AJ (2005). Antinociceptive activity of alcoholic extract of Hemidesmus indicus R. $\mathrm{Br}$. in mice. J. Ethnopharmacol. 102:298-301.

Vianna GSB, Vale TG, Rao VSN, Matos FJA (1998). Analgesic and antiinflammatory effects of two chemotypes of Lippia alba: A comparative study. Pharm. Biol. 36:347-351.

Vieira-de-Abreu A, Amendoeira FC, Gomes GS, Zanon C, Chedier LM, Figueiredo MR, Kaplan MA, Frutuoso VS, Castro-Faria-Neto HC, Weller PF, Bandeira-Melo C, Bozza PT (2005). Anti-allergic properties of the Bromeliaceae Nidularium procerum: Inhibition of eosinophil activation and influx. Int. Immunopharmacol. 5:1966-1974. 